Dorota Żywczak

Uniwersytet Papieski Jana Pawła II w Krakowie

\title{
Pope Benedict XII (1334-1342). The Guardian of Orthodoxy, ed. I. Bueno Amsterdam University Press, Amsterdam 2018, 278 pp.
}

Benedict XII (1334-1342). The Guardian of Orthodoxy is the newest and the most up-to-date monograph of the third Avignon pope. The publication, edited by Irene Bueno from the University of Bologna, consists of the editor's introduction, nine articles written by different authors, a table of abbreviations, a list of illustrations, an index of names and an index of subjects. The book is a fruit of the session 'Inquisition, crusade, and theological disputes during the career of Benedict XII' organised by the editor at the 2012 International Medieval Congress in Leeds.

In popular awareness Benedict XII is better known as Jacques Fournier, the bishop of Pamiers, whose inquisitorial registers underlied the plot of Emmanuel Le Roy Ladurie's famous "Montaillou. Cathars and Catholics in a French Village 1294-1324" (also known under the title "Montaillou: the Promised Land of Error"). However, the monograph presents him both as a bishop and a pope against a wide range of aspects, aiming at sheding some light on different shades of his orthodoxy.

In a straightforward introduction Irene Bueno presents the person of pope Benedict XII to the reader, who - acquainted with necessary knowledge, facts and dates - can then smoothly proceed to getting familiar with new research provided by the authors of subsequent articles. The editor also briefly summarises the content of the book to the reader, so that the authors' intentions can be better understood.

Dorota Żywczak, Pope Benedict XII (1334-1342). The Guardian... 
First chapter is devoted to Benedict XII as Jacques Fournier, the bishop of Pamiers and an inquisitor who broke with thirteenth-century inquisitorial methods by some variations in the type of inquiry style. The article provides a professional, supported by sources juxtaposition of prior and altered inquisitorial proceeding. The chapter is not a dry presentation of facts. The author, Elizabeth Sherman from St Charles Comunity College, not only quotes the bishop's registers and interprets them, but also features concrete individuals occurring in the documents and analyses how they looked in the mirror of Fournier's investigation.

Chapter two reminds the reader that the bishop of Pamiers, apart from being a competent inquisitor, was also an eminent theologian. Here Jacques Fournier appears as a most probable author of a theological advice or opinion given during the final phase of the trial against the heretic treatise "Commentary on the Apocalypse" by the Franciscan theologian Peter John Olivi. The article by Sylvain Piron from École des Hautes Études en Sciences Sociales in Paris unveils a less known face of the bishop of Pamiers - a notable theologian and apologist on the service of orthodoxy.

The third article, written by Christian Trottmann from Centre National de la Recherche Scientifique, shows another side of the protagonist, who stood up for the Catholic doctrine in a very specific context. His predecessor, John XXII, was said to believe that saintly souls after the particular judgment see only the humanity of Christ and will be able to contemplate His divinity only after the Last Judgment. The article shows Benedict XII in the face of a difficult task of formulating the proper doctrinal stance on John XXII's statement and at the same time avoiding accusing his antecessor of heresy.

Chapter four is dedicated to the pope less as an orthodox; Valérie Theis from École Normale Supérieure de Paris focuses on him more as a host in Avignon and a master to Comtat Venaissin. In this way the author adopts an attitude to the fact that she herself indicated - that the protagonist attracts more of historians' attention as an inquisitor Jacques Fournier than as pope Benedict XII residing outside of Rome. Theis also argues that the pontiff's contribution to the strengthening of the pontifical institution (with its new centre in Avignon) is underrated.

Another article is an outstanding one. The author approaches the subject from the perspective of art history, more specifically: in the context of changing locations of the half-length image of Benedict XII by Paolo di Siena and its relation with a similar sculpture of pope Boniface VIII by Arnolfo 
di Cambio. Both works of art are kept in Old St Peter's and the author (Claudia Bolgia from the University of Edinburgh) juxtaposes them in an original way, based on new research. She provides pictures of the discussed works of art and makes a point of the significance of a monumental sculpture of Benedict XII in Rome at the times when the pope resided in Avignon.

The sixth chapter by Sylvain Parent from École Normale Supérieure de Lyon shows Benedict XII against the background of a complex political situation in Italy at that time. Being a successor to John XXII, he was also an heir to the opposition of Northern Italy against papal authority. This politically-tinged article depicts the pope as someone who hated unrest and war and stood for policy of appeasement. The author describes how Benedict XII dealt with the existing political conflicts after their climax during the pontificate of John XXII.

Another part of the book continues the political thought of the previous one as it shows the pontiff's diplomatic efforts on the eve of the Hundred Year's War. Barbara Bombi from the University of Kent discusses Benedict XII as a diplomat and a peacemaker and argues that the outbreak of the war shouldn't be perceived as a proof of the pope's diplomatic idleness. The article contains a description of all the steps taken by Benedict XII in different areas to prevent the outbreak of the warfare.

The penultimate chapter by Mike Carr from the University of Edinburgh introduces the subjects of crusades, that is Benedict XII's crusade strategy as regards the Eastern Mediterranean, Iberia and north-eastern Europe. The article proves that the idea of crusades was still very much alive in the $14^{\text {th }}$ century and that the pope had no choice but to take steps against the Turkish invasion. The author shows yet another face of pope Benedict XII as a guardian - this time as the guardian of faith.

The editor himself wrote the final part of the monograph, which is dedicated to the pontiff's Oriental policies and 'the pope's different attitudes towards non-Catholic, non-properly Catholic and non-Christian peoples'. Irene Bueno puts the protagonist against those who were the farthest from orthodoxy. He adopts a wider perspective on Benedict XII's role, depicting him as a universal shepherd.

Benedict XII (1334-1342). The Guardian of Orthodoxy is a mine of new knowledge on the third Avignon pope and a multi-faceted analysis of his pontificate, which is approached from many different perspectives: theological, doctrinal, political, diplomatic, geographic and many others. The topics of the essays are well-chosen and look intriguing to the reader. All the 
texts are strongly based on sources, which are abundantly quoted in the original. The editor's authorship of the first and the last chapter of the book constitutes a praiseworthy compositional device and makes the impression that the editor took good care of the whole process of preparing the book, from the beginning to the end.

The publication is a monograph, ergo a book, while including the abstracts and key words (useful as they are) makes it look somewhat like a scientific journal. But maybe such were the demands of the series "Church, Faith and Culture in the Medieval West", which the book represents. Another thing is that the publication could contain more illustrations, for example photographs of the quoted documents (especially Jacques Fournier's inquisitorial registers), which would definitely enrich such well-written articles. What's more, no bibliography is provided, while many noted scientific publications are mentioned and the reader has to look annotations over in order to find them.

Despite these small drawbacks, Benedict XII (1334-1342). The Guardian of Orthodoxy is definitely a recommendable book. It's a very modern compilation of immersive articles based on thorough scientific research. The monograph shows Benedict XII as a utility figure with great awareness of his role and with an ability to take care of the pontifical institution - in many ways. Most of the authors of the articles argue that this pope is an underrated one, overshadowed by his predecessor, John XII and his successor, Clement VI. This leads to the conclusion that the pontificate of pope Benedict XII is still a good subject for further scientific research. 